\title{
Slobodna volja između filozofije i znanosti
}

\author{
Filip Grgic *
}

\begin{abstract}
Sažetak
U ovom radu raspravljam o statusu znanstvenih pogleda na slobodu volje, osobito danas raširenih gledišta da je sloboda volje iluzija. Tvrdim, kao prvo, da je problem slobode volje u prilično strogom smislu riječi konceptualan problem, drugo, da je ono što nazivamo problemom slobode volje neodvojivo od konteksta unutar kojega je nastalo, a to je filozofski pokušaj rješenja navodnoga sukoba između slobode i determinizma, i da izvan toga okvira nema nikakvoga značenja te, treće, da je izrazu "sloboda" kako se rabi u znanstvenim i filozofskim stavovima o tom problemu također nemoguće dati značenje izvan toga okvira. Odatle slijedi, između ostaloga, da definitivno rješenje problema slobode volje nije moguće dati, ali da to za ljudske živote ne mora biti osobito važno.
\end{abstract}

Ključne riječi: determinizam, filozofija, indeterminizam, slobodna volja, znanost

\section{Uvod}

Ne, nemate slobodnu volju. To je bio naslov predavanja što ga je američki biolog Jerry Coyne održao u listopadu 2018. godine na Filozofskom fakultetu Sveučilišta u Zagrebu. U njemu je Coyne iznio zamisli koje su dobro poznate i površnomu pratiocu znanstvenih rubrika popularnih medija. U svojoj kolumni u USA Today 1. siječnja 2012. godine Coyne je ovako obrazložio svoje stajalište:

Možda ste izabrali čitati ovaj ogled nakon što ste pregledali ostale članke na ovoj mrežnoj stranici. Ili, ako ste u hotelu, možda ste odlučili što da naručite za doručak ili što ćete danas obući.

Niste ništa izabrali ili odlučili. Možda imate osjećaj da ste nešto izabrali, no u stvarnosti vaša je odluka da čitate ovaj tekst, kao i vaša odluka da jedete jaja ili palačinke determinirana davno prije nego što ste je bili svjesni — možda čak i prije nego što ste se danas probudili. A vaša 'volja' u toj odluci nije igrala nikakvu ulogu. Tako je sa svim našim drugim izborima — nijedan od njih nije ishod naše slobodne i svjesne odluke. Nema slobode izbora, nema slobodne volje. [...] Raspravi o slobodnoj volji, koja je dugo bila u nadležnosti samo filozofâ, znanstvenici, osobito neuroznanstvenici koji

* Prof. dr. sc. Filip Grgić, Institut za filozofiju. Adresa: Ul. Grada Vukovara 54, 10000 Zagreb, Hrvatska. E-adresa: filip@ifzg.hr 
proučavaju kako funkcionira mozak, dali su nov život. A ono što iznalaze podupire zamisao da je slobodna volja potpuna iluzija. ${ }^{1}$ (Coyne, 2012a)

Coyne nije usamljen u takvim tvrdnjama. Psiholog i neuroznanstvenik Michael Gazzaniga tvrdi da »neuroznanost otkriva da je pojam slobodne volje bez značenja [...]. Vrijeme je da prevladamo ideju slobodne volje i krenemo dalje « (Gazzaniga, 2012). Psiholog Paul Bloom također je jasan:

Zdravi razum kaže nam da postojimo izvan materijalnoga svijeta — povezani smo sa svojim tijelom i svojim mozgom, no mi sami nismo materijalna bića, tako da možemo djelovati na načine koji su izuzeti iz fizikalnih zakona. Za svaku odluku koju donesemo [...] naše radnje nisu determinirane i nisu nasumične, nego su nešto drugo, nešto što opisujemo kao izabrano.

To je ono što mnogi nazivaju slobodnom voljom, a većina znanstvenika i filozofa slaže se da je to iluzija. Naše su radnje zapravo doslovno predodređene, determinirane zakonima fizike, stanjem svemira, davno prije nego što smo rođeni te, možda, nasumičnim događajima na kvantnoj razini. Mi ne izabiremo ništa od toga, tako da slobodna volja ne postoji. (Bloom, 2012)

Biolog Anthony Cashmore također smatra da je zamisao da postoji slobodna volja iluzija, koja je perzistirala dok znanost nije opovrgnula kartezijanski dualizam: »Ako više ne uživamo u luksuzu vjerovanja u 'magiju duše', onda je preostalo malo toga što bi poduprlo pojam slobodne volje. Iako je napisano puno radova u kojima se tvrdi da se pruža objašnjenje slobodne volje, u tim radovima u pravilu nedostaje ikakva naznaka molekularnih pojedinosti koji se tiču mehanizama« (Cashmore, 2010, 4499).

Taj niz citata mogu završiti riječima psihologa Johna Bargha:

Što se tiče psihološkoga pojma slobodne volje, gore razmotrena građa, zajedno sa supstancijalnom zalihom znanja što su ga već skupile druge prirodne znanosti, vodi zaključku da nema potrebe postulirati postojanje slobodne volje da bi se objasnio nastanak behavioralnih impulsa, te da nema potrebe postulirati slobodnu volju da bi se objasnilo kako se ti (nesvjesni) impulsi organiziraju i integriraju da bi proizveli ljudsko ponašanje i druge više mentalne procese. Fenomenološki osjećaj slobodne volje veoma je stvaran, a kod onih znanstvenika koji argumentiraju protiv njezina zbiljskoga postojanja jednako je stvaran kao i kod bilo koga drugoga, no taj snažan osjećaj je iluzija, onoliko koliko je iluzija i naš doživljaj Sunca kako se kreće nebom, dok smo zapravo mi ti koji se krećemo. (Bargh, 2008, 148-149)

Popis znanstvenika koji, u ovoj ili onoj verziji, tvrde da slobodna volja ne postoji, odnosno da je osjećaj da imamo slobodnu volju samo iluzija, prilično je dugačak i uključuje, pored gore spomenutih, primjerice biologa Francisa Cricka (1994, 3, 265-268), fizičara Stephena Hawkinga (Hawking i Mlodinow, 2010, 31-32), neuroznanstvenika Benjamina Libeta (1985; 1999; Haggard i Libet, 2001), psihologa Daniela Wegnera (2002), neuroznanstvenika Patricka Haggarda (Haggard i Libet, 2001; usp. Chivers, 2010), neuroznanstvenika Reada Montaguea (2008), neuroznanstvenika Sama Harrisa (2012) i druge. Naravno, tvrdnja da je slobodna volja iluzija ne predstavlja konsensus u znanstvenoj zajednici.

1 Citate je na hrvatski jezik preveo autor rada. 
Mnogo je onih koji su puno oprezniji i koji se suzdržavaju od iznošenja tako jakih tvrdnja. No razumljivo je zašto stavovi poricateljâ nailaze na puno veći odjek u popularnim medijima. Njihove su tvrdnje prilično snažne i, ako su istinite, to bi, kako se barem čini, moglo imati važne posljedice za naš život — za pravni sustav, međuljudske odnose, kao i za stavove što ih svatko od nas ima o samom sebi. K tomu, autori tih tvrdnja ugledni su znanstvenici, koji su ostvarili važne, često i prijelomne rezultate u svojem području istraživanja, tako da nije iznenađujuće što njihovi stavovi u pravilu izazivaju veliku pozornost.

S druge strane, problem slobode volje tradicionalan je filozofski problem, a visoka razina suptilnosti i tehničke sofisticiranosti koje nalazimo u suvremenim filozofskim raspravama o njemu, osim što je standardno obilježje današnje filozofije, pokazuje s kojom ozbiljnošću filozofi pristupaju tomu problemu. No zašto se toliko mučiti oko njega ako tako ugledni znanstvenici već imaju rješenje? Naravno, na to možemo odvratiti tvrdeći da oni sigurno nemaju rješenje — ili su brzopleti ili si u svojim popularnijim napisima mogu priuštiti grandiozne i bombastične tvrdnje ili su im jednostavno stavovi u nekim važnim vidovima manjkavi. No čak i ako je tako, koji je točno status njihovih tvrdnja, kao i tvrdnja onih znanstvenika koji su puno oprezniji i suzdržavaju se od iznošenja definitivnih stavova o ljudskoj slobodi? Coyne u gornjem citatu kaže da je rasprava o slobodnoj volji dugo bila u nadležnosti samo filozofâ, a da su joj znanstvenici, osobito neuroznanstvenici, dali nov život. Stavimo li na stranu povijesnu nepreciznost te izjave, ona izaziva važno pitanje: koji je to novi život što ga je tradicionalni problem slobode volje zadobio tako snažnom znanstvenom intervencijom u nj, koje smo svjedoci osobito posljednjih desetljeća? U kojoj je mjeri uopće tradicionalan problem slobodne volje znanstveni problem?

U ovom tekstu iznosim nekoliko općenitih razmišljanja o tim pitanjima. Ne ulazim u pojedinosti. Samo u prvom odjeljku klasificiram glavne razloge koji znanstvenike navode na skepticizam u pogledu slobode volje te kratko raspravljam o njima, kao i o najvažnijim filozofskim argumentima protiv njih. Zanima me načelan odgovor na pitanje o tom koji je zapravo domet znanstvenih, ali i filozofskih stavova o problemu slobode volje. ${ }^{2} \mathrm{U}$ drugom i trećem odjeljku tvrdim tri stvari: prvo, da je problem slobode volje u prilično strogom smislu konceptualan problem; drugo, da je ono što nazivamo "problem slobode volje" neodvojivo od konteksta unutar kojega je nastalo, a to je filozofski pokušaj rješenja navodnoga sukoba između slobode i determinizma, i da izvan toga okvira nema nikakvoga značenja; treće, da je izrazu "sloboda" kako se rabi u znanstvenim i filozofskim stavovima o tom problemu također nemoguće dati značenje izvan toga okvira. Odatle proizlaze neke važne posljedice za ono što uopće možemo očekivati kao "rješenje" toga problema, o čemu raspravljam u posljednjem odjeljku.

2 Kada govorim o "znanstvenim" stavovima o problemu slobode volje, tada mislim isključivo na stavove koje izričito iznose neki znanstvenici. Isto tako, pod "znanstvenicima” u daljnjem tekstu mislim samo na one koji iznose neke izričite zaključke o slobodi volje. 


\section{Razlozi znanstvenoga skepticima}

Pojednostavljeno govoreći, mogli bismo izdvojiti četiri skupine razloga koji znanstvenike navode na poricanje postojanja slobode volje. ${ }^{3}$

\subsection{Determinizam}

Ponovno možemo navesti tipičan citat iz Coynea:

Slobodnu volju shvaćam onako kako ju, mislim, shvaća većina ljudi: u trenutku kad trebate odlučiti između alternativa imate slobodnu volju ako ste mogli izabrati drukčije. Govoreći u više tehničkom smislu, kad biste vrpcu svojega života mogli odvrtjeti ponovno do trenutka kad donosite izbor, pri čemu je svaki vid svemira konfiguriran na identičan način, slobodna volja znači da je vaš izbor mogao biti drukčiji.

Iako tu vrpcu ne možemo za stvarno ponovno odvrtjeti, ta vrsta slobodne volje isključena je, u jasnom i odlučnom smislu, zakonima fizike. Vaš mozak i tijelo, prijenosnici koji provode 'izbore', sastavljeni su od molekula, a organizacija tih molekula u cijelosti je determinirana vašim genima i vašim okolišem. (Coyne, 2012b)

Zamisao je jednostavna: slobodna volja ne postoji zato što je ono što nazivamo odlukama, pa potom i slobodnim odlukama, rezultat biokemijskih procesa u mozgu, koji se ravnaju po determinističkim zakonima prirode. Stoga naše odluke nisu mogle biti drukčije nego kakve su bile, jer neminovno proizlaze iz determinističkih procesa. Znanost uspješno razotkriva pojedinosti tih procesa i time ujedno pokazuje da slobodna volja ne postoji. To je barem prešutna pretpostavka mnogih znanstvenih pristupa problemu slobode volje. Ponekad je združena s tvrdnjom da čak i ako se pretpostavi da fizika otkriva da je svijet u osnovi indeterministički, sloboda volje ostaje iluzija, jer indeterministički procesi na kvantnoj razini ne mogu osigurati onaj stupanj svjesne kontrole koji je potreban za pripisivanje slobode (usp. Greene i Cohen, 2004, 1777; Libet, 1999, 55-57).

Filozofi na to mogu odgovoriti na jednostavan način. Mogu uputiti na dugu filozofsku tradiciju kompatibilizma, gledišta da su postojanje slobodne volje i istinitost determinizma spojivi, te na činjenicu da je u kompatibilističkoj tradiciji ponuđen niz argumenata preko kojih se ne može tek tako, prešutno prijeći. Iako je kompatibilizam, kako se čini, prevladavajuće stajalište u suvremenoj filozofiji (usp. Bourget i Chalmers, 2013), znanstvenici koji pišu o slobodnoj volji ne uzimaju ga osobito ozbiljno. Primjerice, Harris $(2012,18)$ kaže da »više nego bilo u kojem drugom području akademske filozofije rezultat [kompatibilističke literature] nalikuje teologiji«.

\subsection{Naturalizam}

Svoje argumente protiv postojanja slobodne volje znanstvenici često zasnivaju na pretpostavci da slobodna volja zahtijeva neku nenaturalističku osnovu, prije svega neki oblik kartezijanskoga psihofizičkoga dualizma. Primjer toga možemo naći u gore citiranim riječima Paula Blooma i Anthonyja Cashmorea, kao i u sljedećim mislima Reada Montaguea: 
Slobodna je volja ideja da činimo izbore i imamo misli neovisno o ičemu što i najmanje sliči fizičkomu procesu. Slobodna je volja blizak rođak ideje duše — zamisli da 'ti', tvoje misli i osjećaji, potječu od nekoga entiteta koji je odvojen i različit od fizičkih mehanizama koji sačinjavaju tvoje tijelo. Iz te perspektive, tvoji izbori nisu uzrokovani fizičkim događajima, nego, naprotiv, izviru u cijelosti formirani iz nekoga neopisivoga mjesta, izvan djelokruga fizikalnih opisa. (Montague, 2008, 584)

Slično tomu, Michael Gazzaniga tvrdi da »u tradicionalnoj filozofiji slobodna je volja vjerovanje da je ljudsko ponašanje izraz osobnoga izbora koji nije determiniran fizičkim silama, Sudbinom ili Bogom « (Gazzaniga, 2011, 108; usp. Mele, 2014a, 83-84; 2014b, 195-196).

Filozofski odgovor na takve razloge za poricanje slobodne volje može biti sličan onomu koji vrijedi za prethodnu skupinu razloga. Jednostavno, slobodna volja ne zahtijeva postojanje nematerijalne duše, a naše odluke ne zahtijevaju postojanje bilo kakvih nefizičkih procesa. To ne pokazuje samo duga tradicija kompatibilizma. Ni golema većina inkompatibilista — onih koji smatraju da je postojanje slobodne volje nespojivo s istinitošću determinizma — ne postuliraju u svojim teorijama postojanje nefizičkih entiteta i procesa. Znanstvenici obično pišu da stavovi nestručnjaka, tzv. "običnih ljudi”, o slobodi volje uključuju dualističke pretpostavke. No ni to nije točno: njihovi su stavovi uglavnom lišeni ikakvih metafizičkih pretpostavaka (Monroe i Malle, 2015).

\subsection{Epifenomenalizam}

U ovu skupinu možemo svrstati najozbiljnije i danas najšire raspravljane znanstvene argumente protiv postojanja slobodne volje. Ono što ih povezuje jest, najopćenitije govoreći, tvrdnja da je svijest epifenomenalna, to jest da ne igra nikakvu kauzalnu ulogu u procesima koji dovode do radnje. Budući da postojanje slobodne volje, kako se čini, pretpostavlja da djelatnik svjesno inicira proces koji dovodi do radnje, čini se da, ako svijest ili svjesna odluka nije inicijator naših radnja, onda one ne mogu biti manifestacija naše slobodne volje.

Glavni izvori za takvu vrstu argumentacije dolaze iz neuroznanosti i psihologije. Osobito su potaknuti radovima Benjamina Libeta osamdesetih godina prošloga stoljeća, koji upućuju na činjenicu da svijest o odluci ili namjeri da se izvede jednostavna radnja kao što je svijanje zgloba kasni oko 350 milisekundi za detektiranom aktivnošću u suplementarnom motornom području mozga, zaduženom za kontrolu kretanja. Libetovi su eksperimenti i rezultati obilno replicirani i raspravljani, te su izazvali veliku pozornost. U novije vrijeme provedeni su neki sofisticiraniji eksperimenti, za koje se smatra da su dodatno potvrdili Libetovu paradigmu i zaključak da je svijest epifenomenalna. Jedan je eksperiment tako pokazao da »dva specifična područja u čeonom i tjemenom režnju ljudskoga mozga sadržavaju znatne informacije koje predviđaju ishod motorne odluke koju subjekt još nije svjesno donio. To sugerira da kada je subjektova odluka došla do svijesti, ona je do 10 sekundi već bila pod utjecajem nesvjesne moždane aktivnosti« (Soon et al., 2008, 545). Točnost predviđanja odluke (hoće li subjekt pritisnuti lijevi ili desni gumb) iznosila je oko 60\%. U jednoj novijoj studiji (Fried et al., 2011) točnost je skočila na $80 \%$. U tu skupinu razloga u prilog skepticiz- 
mu u pogledu slobodne volje možemo uključiti i one koje iznosi Daniel Wegner (2002), koji tvrdi da je naš osjećaj svjesne volje i svjesnih namjera kao nečega što uzrokuje radnje iluzija, te da su naše radnje zapravo ishodi nesvjesnih procesa.

Filozofske reakcije na te i slične studije brojne su i upućuju na nekoliko problema (usp. Mele, 2014a, 2014b; Nahmias, 2014). Neki su sasvim općenite naravi i tiču se, primjerice, činjenice da provedeni eksperimenti ne omogućuju generalizacije na složene radnje. Ono što vrijedi za jednostavne radnje kao što je svijanje zgloba ili pritiskanje gumba ne mora vrijediti za složene procese odlučivanja, koji uključuju odvagivanje razlogâ za djelovanje na ovaj ili onaj način, a takve su radnje one čija nas sloboda prvenstveno zanima. Druge se skupine prigovora tiču pojedinostî opisa eksperimenata, primjerice pitanja označava li početak nesvjesne neuralne aktivnosti početak formiranja odluke ili namjere, ili pak samo poriva ili spremnosti da se kasnije formira odluka ili namjera. Isto tako, eksperimenti ne pokazuju da je nesvjesna neuralna aktivnost dovoljan uzrok radnje (Libet ne govori o slučajevima kada dolazi do neuralne aktivnosti, ali ne i do radnje; usp. Nahmias, 2014, 14). Naposljetku, čak i ako se pretpostavi da radnja započinje s nesvjesnom neuralnom aktivnošću, to ne znači da se time isključuje mogućnost da je radnja slobodna (usp. odjeljak 3). U svakom slučaju, u ovom području možemo očekivati daljnju burnu raspravu.

\subsection{Izazovi socijalne psihologije}

U novije je vrijeme niz autora upozorilo na činjenicu da neki uvidi iz socijalne psihologije, osobito iz situacionističke literature, dovode u ozbiljno pitanje pretpostavku da imamo slobodnu volju. Situacionistička se postavka u najopćenitijem smislu može formulirati kao tvrdnja da su ljudske radnje u većoj mjeri u korelaciji s obilježjima konkretnih situacija nego s postojanim karakternim crtama (Garvey, 2018, 73). Nekoliko je skupina razloga na temelju kojih se odatle može izvesti neka varijanta skepticizma u pogledu slobodne volje i moralne odgovornosti (Nelkin, 2005; Vargas, 2013; Miller, 2017; Garvey, 2018). Jedna se skupina razloga tiče činjenice da je jedna od glavnih implikacija situacionizma nijekanje stabilnih karakternih crta koje bi bile nepromjenljive u različitim pojedinačnim situacijama, a s druge strane čini se da tipični primjeri slobodnih radnja jesu radnje koje proizlaze iz postojanoga karaktera. No to se obično odbacuje kao nedovoljno čvrst razlog za skepticizam u pogledu slobodne volje, barem zbog toga što ne moraju sve slobodne radnje biti manifestacije karaktera. Ponešto je uvjerljiviji prigovor koji se iz situacionističkoga tabora može uputiti onim filozofima prema kojima sloboda i moralna odgovornost zahtijevaju prije svega sposobnost reagiranja na razloge. Primjer za to je utjecajna teorija koju su razvili Fischer i Ravizza (1998). No eksperimenti na koje se situacionisti najčešce pozivaju, kao što je poznati Milgramov eksperiment poslušnosti autoritetu, sugeriraju da ljudi u specifičnim situacijama lako gube sposobnost reagiranja na relevantne, prije svega moralne razloge. Naposljetku, utjecaj situacijskih čimbenika može biti takav da ljudi djeluju iz nesvjesnih motiva, što je također razlog da im zaniječemo slobodnu volju. 


\section{Slobodna volja kao konceptualni problem}

\section{1. Što je problem slobode volje?}

To su, dakle, glavne skupine razloga koji znanstvenike navode na skepticizam u pogledu slobodne volje, kao i neki filozofski odgovori na njih. Glavni problem s tim znanstvenim stavovima ne sastoji se u tom što niječu postojanje slobodne volje ili u tom što su u nekom vidu manjkavi ili pogrešni. Možemo pretpostaviti da će se razvojem znanosti ti nedostatci postupno uklanjati i da će slika koju dobivamo od znanosti postajati potpunija i točnija. Uostalom, ono što me ovdje zanima nisu pojedinosti, nego načelni status znanstvenih, ali i filozofskih tvrdnja o slobodi volje. Jedan načelni problem sigurno se sastoji u tom što su znanstvene tvrdnje često brzoplete i uključuju neutemeljene generalizacije, što se osobito odnosi na posljednje dvije skupine razloga. No ni taj prigovor ne možemo smatrati odlučujućim. Ponekad je brzopletost jednostavno izraz stila ili je pak riječ o prilagođavanju prigodi i mediju u kojem se stavovi iznose.

Ozbiljniji se prigovor tiče činjenice da su znanstveni stavovi o slobodi volje u mnogim slučajevima zasnovani na upitnim metafizičkim i konceptualnim pretpostavkama. Često se zasnivaju na pretpostavci da sloboda volje zahtijeva psihofizički dualizam i neki oblik nenaturalizma, što sigurno nije točno. Isto tako, znanstvenici se često, bez prethodnih istraživanja, pozivaju na stavove što ih o slobodnoj volji navodno imaju tzv. "obični ljudi”. Greene i Cohen $(2004,1779)$ tako kažu da je »većina gledišta što ih ljudi zastupaju o umu implicitno dualistička i libertarijanska, a ne materijalistička i kompatibilistička «. Što se tiče intuicija o slobodi volje, to sigurno nije točno: dosadašnja istraživanja eksperimentalnih filozofa pokazala su da ljudi zastupaju i kompatibilističke i inkompatibilističke intuicije, ovisno o pitanjima koja im se postavljaju, demografskom uzorku i dr. (Knobe i Nichols, 2017).

Općenitiji i jednostavniji problem sa znanstvenim objašnjenjima slobodne volje jest u tom što ona zanemaruju mjeru u kojoj je problem slobode volje konceptualan. Ona ga ili u cijelosti shvaćaju kao empirijski problem ili konceptualne poteškoće toliko podcjenjuju da ispada trivijalan. Da bismo shvatili što znači tvrditi da je problem slobode volje konceptualan, trebamo malo preciznije odrediti što je točno taj problem.

Tradicionalno se problem slobode volje shvaća onako kako se obično, osobito u raznim vrstama uvoda u filozofiju, shvaćaju filozofski problemi: kao problem sukoba između dviju ili više tvrdnja koje se smatraju istinitima. U slučaju problema slobode volje imamo, s jedne strane, tvrdnju da slobodna volja postoji, to jest da barem neki ljudi imaju slobodnu volju, te, s druge strane, tvrdnju da svijet funkcionira na određeni način, naime na način za koji se čini da je u sukobu s uvjerenjem da postoji slobodna volja. Tradicionalno se pretpostavlja da ono što je u sukobu s uvjerenjem da postoji slobodna volja jest zamisao da svijet funkcionira deterministički. Takva je karakterizacija uobičajena barem posljednjih nekoliko stoljeća, od doba kada je — razvojem newtonovske fizike te Boškovićevim i potom Laplaceovim formulacijama determinizma (usp. Kožnjak, 2015) — pojam 
determinizma postupno zamijenio starije pojmove nužnosti, sudbine, neumitnosti, providnosti i sl. (od kojih neki i dalje ponekad figuriraju u opisu problema). U filozofskim se raspravama determinizam određuje na nekoliko načina, koji se svi više-manje svode na isto. Tako se pod determinizmom ponekad misli na kauzalni determinizam, to jest na tezu prema kojoj je svaki događaj nužan učinak nekoga prethodnoga uzroka. No kako bi se izbjeglo upuštanje u složeno pitanje o naravi uzročnosti, možda je bolje determinizam definirati akauzalno, kao tezu prema kojoj stanje svijeta u bilo kojem trenutku, uz prirodne zakone, nužno povlači stanje svijeta u drugom trenutku. Dakle, ako su $p$ i $q$ propozicije koje izražavaju stanje svijeta u različitim trenutcima, onda konjunkcija $p$ i prirodnih zakona povlači $q$. To je u osnovi formulacija koju je predložio Peter van Inwagen (1983, 65) i koja je standardna u suvremenim raspravama. Ako je determinizam istinit, onda postoji samo jedna fizički moguća budućnost: iz prošlosti i prirodnih zakona može slijediti samo jedna budućnost. Razumljivo je zašto postojanje slobodne volje mnogi smatraju nespojivim s tvrdnjom da svijet funkcionira deterministički, to jest zašto mnogi osjećaju snažnu privrženost inkompatibilizmu. U njihove razloge ovdje ne trebam ulaziti. Htio bih naglasiti nešto drugo.

Htio bih naglasiti, kao prvo, da ono što je navodno suprotstavljeno istinitosti determinizma nije tek osjećaj slobode. Naravno, ako su inkompatibilisti u pravu, onda, ako je determinizam istinit, naš osjećaj da smo slobodni samo je iluzija. No to nije ono u čemu se sastoji problem slobode volje. Prije svega, nije jasno postoji li uopće nešto takvo kao što je osjećaj slobode koji je takav da ima samo fenomenološki, a ne i konceptualni sadržaj, dakle osjećaj slobode koji nije zasnovan na nekom prethodno usvojenom pojmu slobode ili nekom vjerovanju o slobodi. ${ }^{4}{ }^{4}$ Cak i ako nešto takvo postoji, ono što nas zanima kada razmišljamo o problemu slobode volje jest pitanje postoji li nešto što naša vjerovanja o tom da smo slobodni ili da smo pravno ili moralno odgovorni djelatnici čini istinitima, te, ako postoji, što je to. Drugim riječima, zanima nas je li naš pojam slobode instanciran u svijetu.

Drugo, ono na što mislimo kad govorimo o problemu slobodne volje upravo je opisani tradicionalni problem — problem navodnoga sukoba između postojanja slobodne volje i istinitosti determinizma. To je tradicionalno značenje izraza "problem slobode volje", i to je ono na što mislimo kada danas govorimo o tom problemu. Izvan filozofije, ili izvan okvira u kojem je nastao, taj problem ne postoji, upravo u onom smislu u kojem izvan filozofije ne postoji nešto takvo kao što je primjerice problem postojanja vanjskoga svijeta, problem ustrajavanja predmetâ kroz vrijeme ili problem moralnoga realizma ili antirealizma. Ako je problem slobode volje i postao dijelom šire, popularne kulture, i ako je, k tomu, postao predmetom interesa znanstvenikâ, takvim je postao zato što je u kulturu i znanost ušao iz tradicionalnoga — filozofskoga — okvira unutar kojega je nastao.

Treće, isto vrijedi i za izraz "slobodna volja". Taj izraz svoje značenje ima isključivo kao dio tradicionalnoga problema slobode volje. On je također neod-

4 Primjerice, Paglieri (2013) tvrdi da takav pozitivan fenomenološki sadržaj ne postoji, nego da sud o tome da je neka radnja slobodna zahtijeva samo to da subjekt nema osjećaj prinude. 
vojiv od okvira unutar kojega je nastao: slobodna je volja, jednostavno, ono čije postojanje neki smatraju ugroženim kada razmišljaju o posljedicama prihvaćanja determinizma. Slobodna je volja filozofska konstrukcija čiji je vijek trajanja neraskidivo vezan uz vijek trajanja okvira unutar kojega je taj pojam nastao i kojemu pripada. Izvan toga okvira upućivanje na slobodnu volju često nije ništa više od upućivanja na činjenicu da ono što je učinjeno nije rezultat prisile — "to i to činim slobodnom voljom" ne znači ništa drugo do "nitko me ne sili na to i to" (usp. Inwagen, 2017). A izostanak vanjske prinude, prema mišljenju većine filozofa danas, nije dovoljan za pripisivanje slobodne volje.

Stoga način na koji je problem slobodne volje tradicionalno formuliran ne omogućuje isključivo znanstveno rješenje problema, osim ako znanost na sebe ne preuzme konceptualni dio posla. Taj konceptualni dio posla sastoji se u preciznom identificiranju pojma slobode, utvrđivanju njegova mjesta u mreži srodnih pojmova - kao što su pojmovi radnje, namjere, odluke, deliberacije, kontrole, uzroka, odgovornosti itd. — te u iznalaženju nužnih i dovoljnih uvjeta za instancijaciju pojma. Naravno, u taj se posao znanost ne upušta, štoviše podcjenjuje njegovu važnost. Stoga ne čudi što kao pojam za koji tvrdi da nije instanciran uzima pojam koji je u filozofiji u najmanju ruku prijeporan ili ne figurira kao relevantan. Ili se pak koristi pojmom slobode što ga, kako tvrdi, imaju tzv. "obični ljudi”, što je u dvostrukom smislu promašen potez. Prvo, zato što, kako sam spomenuo, "obični ljudi" nemaju neki jedinstven pojam slobode, takav da se može kazati: "Eto, to je ono što ljudi razumiju pod slobodnom voljom.” Drugo, čak i kad bi takav pojam postojao, to bi bilo irelevantno, jer ono o čemu razmišljamo kada razmišljamo o problemu slobodne volje jest nešto što je zadano tradicijom i okvirom određenoga problema: kako vjerovanje da imamo slobodnu volju i sva vjerovanja koja se na tom zasnivaju pomiriti s istinitošću determinizma. A pučki pojam slobodne volje sigurno nije formiran unutar toga okvira.

Tomu se vraćam kasnije. Imamo li u vidu opis problema, jasno je u kojem je smislu problem slobode volje konceptualan i zašto se njegov konceptualni vid jednostavno ne može ukloniti. To bismo mogli objasniti i na sljedeći način.

\subsection{Sloboda i potpun opis svijeta}

Istinitost determinizma nije konceptualno, nego empirijsko pitanje. Empirija je konačni sudac koji može odrediti je li determinizam istinit. No istinitost determinizma sama po sebi baš ništa ne povlači za sobom o tom je li svijet takav da u njemu postoji slobodna volja ili ne. Jer pretpostavimo da je prirodna znanost dovršena - da nam je u stanju ponuditi potpun opis svijeta, to jest skup svih istinitih iskaza o svijetu. Takav potpun opis svijeta sadržavao bi podrobna objašnjenja svih procesa - uključujući, naravno, sve procese u ljudskom mozgu i njegovu okolišu — i na temelju njega bi nam do u krajnju pojedinost bila poznata baš svaka činjenica o svijetu. Pretpostavimo, k tomu, da nam takav opis kaže da svijet funkcionira deterministički: svaki događaj u svijetu, uključujući i one događaje koje nazivamo ljudskim radnjama i odlukama, neumitno slijedi iz nekoga prethodnoga događaja i prirodnih zakona (koji bi nam, po pretpostavci, 
bili svi poznati). Kad bi takav opis svijeta bio istinit, sve teorije slobodne volje koje zahtijevaju neki oblik indeterminizma, naravno, otpale bi. Ali rješenje problema slobode volje ipak ne bismo imali — pitanje "Imamo li slobodnu volju?" ostalo bi otvorenim. Jer takav, dovršeni opis svijeta spominjao bi različite procese i davao njihova deterministička objašnjenja. Objasnio bi nam sve stvari i njihova svojstva. No izrazi "sloboda", "slobodna volja", "slobodan" u njemu se ne bi rabili (osim što bi se možda zadržali izrazi kao što su "slobodni radikali" ili "slobodne varijable"). Ostalo bi nam otvorenim pitanje ima li među opisanim procesima takvih da je za njih istinito kazati da su slobodni i jesu li neki od opisanih procesa takvi da za njih možemo kazati da čine istinitim pripisivanje slobode nekim drugim opisanim procesima, kao što su oni koje nazivamo odlukama ili radnjama, ili nekoj stvari koju nazivamo voljom. To bi pitanje ostalo otvorenim zato što ono što nas zanima kada rješavamo problem slobode volje jest pitanje je li naš pojam slobode instanciran u svijetu, to jest postoji li nešto, i što je to, što naša vjerovanja o slobodi čini istinitima.

Isto vrijedi čak i ako taj osnovni okvir proširimo, to jest čak i ako pretpostavimo da nije determinizam, ili samo determinizam, ono s čim je postojanje slobode u sukobu. Postoje snažni razlozi za tvrdnju da je sloboda volje u sukobu i s indeterminizmom - indeterministički su procesi nasumični i slučajni, a nasumičnost i slučajnost nisu svojstva koja su spojiva s pojmom slobode. Pretpostavimo, kao i maločas, dovršenu prirodnu znanost koja ovoga puta isporučuje potpun opis svijeta prema kojemu svijet u osnovi funkcionira indeterministički. Ili, što je primjerenije, zamislimo da nam dovršena znanost kaže da su relevantni procesi u mozgu i njegovu okolišu u krajnjoj liniji indeterministički, to jest da se u njihovu temelju nalaze indeterministički procesi. Kao i maločas, pitanje o tom postoji li slobodna volja ostalo bi otvorenim. Kao i maločas, ostalo bi otvorenim pitanje možemo li za neke od opisanih indeterminističkih događaja, uključujući i događaje kao što su odluka ili radnja, kazati da su slobodni, to jest možemo li identificirati neke indeterminističke procese koji nisu slučajni ili nasumični u tom smislu da sprječavaju instancijaciju pojma slobode, nego je, štoviše, omogućuju. Indeterministički opis svijeta bio bi prilično složeniji od determinističkoga - na kraju krajeva, sigurno nije sve indeterminirano - no problem bi bio isti.

On bi bio isti - zapravo teži - i kad bi dovršena znanost ponudila sliku svijeta kao mješavine determinističkih i indeterminističkih procesa. No bio bi isti i kad bismo se malo odmaknuli od tradicionalnoga okvira "sloboda versus determinizam/indeterminizam" no slobodu i dalje poimali kao jednu stranu u sukobu. Jer, podsjećam, tradicionalni problem slobode volje svodi se, u osnovi, na sljedeća pitanja: je li, i kako, pojam slobode instanciran u svijetu, to jest postoji li nešto što naša vjerovanja da su neke naše odluke i radnje slobodne čini istinitima te, ako postoji, što je to točno? Vidjeli smo da taj problem ostaje čak i ako znamo da jedino što naša vjerovanja može činiti istinitima jesu deterministički ili indeterministički procesi. No problem ostaje čak i ako, proširujući okvir, tvrdimo da jedino što naša vjerovanja o slobodi može činiti istinitima jesu prirodni procesi, stavljajući na stranu pitanje jesu li ti procesi deterministički ili indeterministički. Jednostavnije rečeno, čak i ako ustvrdimo da je ono s čim je sloboda u sukobu 
zapravo naturalizam, i čak i ako znamo da je naturalizam istinit, problem ostaje neriješen, zbog istog razloga kao i prije — ništa u naturalističkom opisu svijeta, uzetom samom po sebi, ne govori je li u svijetu instanciran pojam slobode. On samo isključuje neke opcije, primjerice zamisao da pripisivanje slobode zahtijeva neku nenaturalističku osnovu. No on isključuje samo to - preostalo područje koje pokriva baš ništa ne govori o tom imamo li slobodu i kakva je.

Stvar bi bila posve ista i kad bi istinitim bio neki nenaturalistički opis svijeta. Jer pretpostavimo, kao prvo, da je definitivno utvrđeno da je naturalistički opis svijeta neistinit zato što postoje, primjerice, nematerijalne duše koje su, k tomu, izvori naših odluka i radnja. Bilo bi krajnje naivno tvrditi da je takav opis svijeta sam po sebi, bez obavljena konceptualnoga dijela posla, dovoljan za rješenje problema slobode volje. Jer sad bi nam se, u drukčijem obliku, javila dilema "determinizam ili indeterminizam": donošenje odluka i iniciranje radnja ishod je ili indeterminističkih ili determinističkih nematerijalnih duševnih procesa, a što god od toga bilo istinitim, nalazimo se $\mathrm{u}$ istim problemima kao i ranije. Pretpostavimo pak, kao drugo, da je naturalistički opis svijeta nepotpun zato što postoje neke na prirodne procese nesvodive činjenice, kao što je činjenica da imamo slobodnu volju. Sam po sebi, takav opis svijeta ne bi uključivao nikakvo objašnjenje, i konceptualni bi posao bio utoliko teži nego u drugim slučajevima.

$\mathrm{Na}$ koncu, pretpostavimo - da dovršim ovo poduže obrazlaganje u kojem je smislu tradicionalni problem slobode volje konceptualan — da je neuroznanost definitivno i nedvosmisleno utvrdila da je svijest epifenomenalna: da svijest o odluci, ili svjesna odluka, uistinu toliko kasni za neurokemijskim procesima koji predstavljaju pravi početak radnje da se može kazati da je ona uzročno u potpunosti jalova te stoga u uzročnom nizu koji dovodi do radnje — bez obzira na to je li on deterministički ili indeterministički - sasvim zaobiđena. Drugim riječima, pretpostavimo da je definitivno i nedvosmisleno utvrđeno da su naše radnje ishodi nesvjesnih procesa u mozgu i da svijest, ili njezini neuralni korelati, pritom ne igra nikakvu ulogu. Pretpostavimo, naposljetku, da je to utvrđeno ne samo za jednostavne radnje, koje ne uključuju izabiranje između različitih opcija, nego i za složene radnje koje sačinjavaju ono što je uistinu važno u našim životima. Na prvi pogled, čini se da bi takvo stanje stvari samo po sebi isključivalo postojanje slobodne volje. Ako je uistinu tako da je cjelokupni naš život upravljan neurokemijskim procesima kojih uopće nismo svjesni, onda se čini da više nema nikakva preostaloga konceptualnoga posla i ispada da je sloboda volje ipak, u krajnjoj liniji, empirijski problem.

Ipak, mislim da bi i pod tom pretpostavkom to bio ishitren zaključak i da bi konceptualna strana i dalje ostala otvorenom, kao i pod prethodnim pretpostavkama. Stvar je u tom da kad bismo pod gornjom pretpostavkom dovršene neuroznanosti, i samo pod njom, tvrdili da sloboda volje ne postoji, tad bismo ponovno pretpostavljali kao dokazano ono što tek treba dokazati, naime da sloboda zahtijeva da svijest ne bude zaobiđena i da bude uzročno aktivna. No postoji filozofska tradicija prema kojoj sloboda ne zahtijeva ništa više od odsutnosti vanjskih prepreka prilikom manifestiranja djelatnikovih želja. Tu tradiciju najbolje predstavlja Hobbesov stav: »Iz uporabe izraza slobodna volja, nikakva se 
sloboda ne može zaključiti o volji ili želji ili sklonosti, nego o slobodi čovjeka, a ona se sastoji u tom da on ne nailazi ni na kakvu prepreku dok čini ono za što ima volju, želju ili sklonost da čini« (Hobbes 2004, 146). Ako pod pojmom slobode razumijemo ono o čemu govori Hobbes, onda ima smisla pitati sadržava li svijet, u kojem je svijest na gore opisani način uzročno zaobiđena, slobodu. Jer, prema hobbesovskom pojmu, za pripisivanje slobode dovoljno je da ne postoje prepreke onomu što su inicirali neuralni korelati volje, želje ili sklonosti, bez obzira na to jesmo li ih svjesni ili ne.

Pogledajmo pak što sredinom 20. stoljeća kaže John L. Austin:

Iako se [sloboda] tradicionalno predstavljala kao 'pozitivni' izraz koji zahtijeva razjašnjenje, malo je sumnje u to da kazati kako smo djelovali ‘slobodno' (u filozofovoj uporabi toga izraza, koja je tek slabašno povezana s njegovom svakodnevnom uporabom) znači kazati samo to da nismo djelovali neslobodno, u nekom od mnogih heterogenih načina na koje se može tako djelovati (pod prinudom ili čim već). Poput izraza 'stvaran', izraz 'slobodan' rabi se samo kako bi se isključila naznaka neke ili svih njegovih priznatih antiteza. Kao što 'istina' nije naziv za neko obilježje tvrdnja, tako 'sloboda' nije naziv za neko obilježje radnja, nego naziv dimenzije u kojoj se radnje procjenjuju. Ispitujući sve načine na koje svaka radnja može a da ne bude 'slobodna', tj. slučajeve u kojima se ne može jednostavno kazati ' $X$ je učinio A', nadamo se da ćemo se riješiti problema slobode. Aristotela su često korili zbog toga što je govorio o izgovorima i izlikama te previđao 'stvarni problem'. U mojem slučaju, tek kad sam počeo shvaćati nepravednost te optužbe, počeli su me zanimati izgovori. (Austin, 1956-1957, 6)

Austinov pojam slobode oskudniji je od Hobbesova. Između "X je učinio A" i "X je slobodno učinio A" razlika je samo u tom što druga rečenica sadržava »naziv dimenzije u kojoj se radnje procjenjuju«, dakle ne upućuje ni na kakvo posebno obilježje radnje. Ona samo naglašava da X nije djelovao neslobodno.

A pogledajmo i Aristotela, na koga se poziva Austin. On uopće nema pojam slobode, nego tek pojam hotimične ili voluntarne radnje: »Budući da je nehotimično (akousion) ono što je učinjeno prisilno i zbog neznanja, čini se da je hotimično (hekousion) ono čije je polazište u djelatniku, kojemu su poznate pojedinačne okolnosti njegova djelovanja« (Aristotel, 1894, 3.1.1111a22-24).

Otvoreno je pitanje instancira li svijet, u kojem je svijest u cijelosti epifenomenalno svojstvo, ono o čemu govore Aristotel, Hobbes i Austin. Točnije, onaj tko želi tvrditi da istinitost takva opisa svijeta sama po sebi isključuje slobodnu volju obvezan je na tvrdnju da istinitost takva opisa isključuje i postojanje ljudskih radnja, hotimičnih radnja i znanja. No ne vjerujem da su znanstvenici spremni obvezati se na nešto takvo.

\section{Pojam slobode}

\subsection{Empirijska i konceptualna dimenzija tradicionalnoga okvira}

Iz razmatranjâ u prethodnom odjeljku netko bi mogao zaključiti da znanstvenicima koji iznose razne tvrdnje o slobodi volje zapravo pripisujem neku vrstu starinske naturalističke pogreške. Drugim riječima, moglo bi se pomisliti da im prigovaram kako svaki iskaz oblika "X je slobodno" pokušavaju izvesti iz nekoga 
prirodnoga (ili, u proširenoj verziji, neprirodnoga ili nadprirodnoga) svojstva, iako je "slobodno" evaluativni ili normativni izraz, poput "dobro", za koji, k tomu, smatram da se ne može izvesti iz činjeničnih premisa. No to nije ono što tvrdim. Ne tvrdim ništa o tom je li sloboda čisto normativni pojam, koji nema metafizičke ili prirodne osnove (iako bih iz sasvim drugih razloga možda bio sklon takvu stajalištu). Tvrdim samo to da ako se problem slobode volje shvati na tradicionalan način, kao sukob ili prividni sukob između pripisivanja slobode i načina na koji funkcionira svijet, onda taj problem ima dva dijela, konceptualni i empirijski, i svaki pokušaj da ga se riješi na isključivo empirijskim osnovama osuđen je na neuspjeh. Filozofi koji insistiraju na normativnom vidu, kao primjerice Strawson (1962), izlaze iz tradicionalnoga okvira problema slobode volje i više uopće ne govore o slobodi volje, nego o moralnoj odgovornosti. No znanstvene tvrdnje o kojima sam raspravljao u prvim dvama odjeljcima ostaju unutar tradicionalnoga okvira.

Ako je uistinu tako da tradicionalni okvir ima dva dijela, onda bi znanstvenici, barem oni koji su iole blagonakloni prema filozofiji, mogli na razmatranja iz prethodnoga odjeljka reagirati ovako: "Ako je problem takav, i ako se mi znanstvenici koji iznosimo tvrdnje o slobodi volje uistinu krećemo unutar tradicionalnoga okvira, onda se mora priznati da smo mi svoj dio posla obavili, ili da ga barem uspješno obavljamo. Fizika, biologija i neuroznanost neprestano i očevidno napreduju i empirijsku stranu problema čine jasnijom. Filozofi su ti koji su zakazali. Oni su ti koji nisu ponudili jasan i usuglašen pojam slobode, takav za koji bi onda oni — a zašto ne i mi? — mogli pitati je li i, ako jest, kako, instanciran u svijetu kakva uspješno opisujemo.”

Ako je takva reakcija primjerena, onda je možda razumljiva, a dijelom i opravdana brzopletost zbog koje ponekad prigovaramo znanstvenicima. Ako na osnovi pojedinačnoga otkrića koje se tiče jednoga maloga segmenta ljudskoga ponašanja odmah generaliziraju pa kažu da to pokazuje da je slobodna volja iluzija, onda se — da budemo jednako blagonakloni — barem dio te brzopletosti može opravdati činjenicom da filozofska literatura ne nudi jasan i usuglašen pojam slobode, onoliko jasan i usuglašen koliko su to standardni pojmovi kojima se koristi znanost. Stoga je razumljivo i to da se znanstvenici pozivaju na pojam slobode što ga navodno rabe nestručnjaci ili “obični ljudi”. Ako pritom pogrešno identificiraju taj pojam, to je dijelom i zato što su filozofi tek protekloga desetljeća počeli sustavnije istraživati što je to što "obični ljudi” razumiju pod slobodnom voljom.

\subsection{Neusuglašenost filozofskoga pojma slobode — jedan primjer}

Spomenuta je reakcija primjerena utoliko što filozofi uistinu nisu ponudili usuglašen pojam ili definiciju slobode. Kad se i ponudi neka definicija za koju se na prvi pogled čini da može biti prihvatljiva svim stranama u sporu, dovoljno je samo malo dodatnoga razmišljanja da se otkrije kako tomu nije tako, prvenstveno zato što će izraze koji se u njoj javljaju razne strane u sporu tumačiti na različite načine. Pogledajmo jednu takvu, naizgled opće prihvatljivu definiciju (usp. McKenna i Pereboom, 2016, 6): Slobodna je volja jedinstvena sposobnost osoba da manifestiraju najsnažniju kontrolu nad svojim radnjama potrebnu za moralnu odgovornost. 
Slobodna je volja, dakle, (1) sposobnost manifestiranja kontrole, i to (2) takve da na osnovi nje osobi možemo pripisati moralnu odgovornost. Na prvi pogled, riječ je o neprijepornoj definiciji — čini se jasnim da se sloboda u prvom redu tiče kontrole koju imamo nad svojim radnjama i da je ona potrebna za pripisivanje moralne odgovornosti. Tu ili sličnu definiciju — u svakom slučaju, takvu koja slobodu definira pomoću pojma kontrole ili pomoću pojma onoga što je do nas ili što je u našoj moći da učinimo — lako mogu prihvatiti svi sudionici suvremenoga spora oko slobode volje. No čim se počne malo podrobnije razrađivati njezin sadržaj, dolazi do razilaženja. Do razilaženja može doći i što se tiče stavke (2). Možemo prihvatiti da nam je sloboda važna zato što se čini da je ona nužan uvjet moralne odgovornosti. Osobu smatramo moralno odgovornom — dakle, opravdanim primateljem pohvale i pokude, kazne i nagrade - ako je slobodna, to jest ako ima sposobnost manifestiranja kontrole nad svojim radnjama, ako su njezine radnje do nje, a ne do nečega ili nekoga drugoga. No jasno je, isto tako, da se sloboda proteže šire od radnja zbog kojih nas se može smatrati moralno odgovornima. Ona se tiče i radnja kao što su izabiranje košulje ili vrste sladoleda, koje, barem u uobičajenim slučajevima, nemaju nikakve implikacije za moralnu odgovornost. Moglo bi se kazati da je ograničavanje na slobodu koja je potrebna za pripisivanje moralne odgovornosti neopravdano, jer iako nam je moralna odgovornost važna, ono što vrijedi za slobodu koja je preduvjet moralne odgovornosti možda ne vrijedi za slobodu u širem smislu.

Ipak, kako danas stvari stoje, (2) je neprijeporno (ili, možda točnije, neprijeporno barem većini filozofa). Problem je u (1). Iako se svi slažu da sloboda zahtijeva sposobnost manifestiranja kontrole, do razilaženja dolazi kada se postavi pitanje što se točno razumije pod kontrolom. Jedna skupina filozofa insistira na tom da relevantan smisao kontrole jest kontrola nad izborom: imati kontrolu nad radnjom A znači imati sposobnost izabrati učiniti A, a ne B (ili ne učiniti ništa). Drugim riječima, ako kažem da imam kontrolu nad onim što činim, onda to znači da je do mene hoću li učiniti ovo ili ono - analitički je istinito tvrditi da je A do mene (u mojoj moći ili pod mojom kontrolom) samo ako mogu učiniti A ili B (ili ne učiniti ništa). Retrospektivno, dakle nakon što sam učinio $A$, kazat ću da je ta radnja bila pod mojom kontrolom zato što sam mogao učiniti i B (ili ne učiniti ništa).

Nesuglasje se javlja oko pitanja što znači imati kontrolu nad izborom. Jedna skupina filozofa smatra da, kako bi se moglo kazati da imam kontrolu nad time hoću li učiniti A ili B, A i B moraju biti stvarno, fizički, otvorene opcije. Drugim riječima, moram vjerovati $\mathrm{u}$ istinitost indeterminizma. Jer kad ne bih vjerovao u istinitost indeterminizma, tad bi to značilo da ostavljam otvorenom mogućnost da svijet funkcionira deterministički, što bi pak značilo da zapravo nemam dvije opcije, nego samo jednu. A u tom se slučaju ne bi moglo kazati da imam sposobnost izabiranja pa stoga ni kontrole. Stoga opcije moraju biti stvarno, fizički, otvorene. Kada, retrospektivno, kažem "Mogao sam učiniti drukčije", tada to znači da sam $\mathrm{u}$ istim okolnostima mogao izabrati drugu, tada jednako stvarnu i otvorenu opciju.

No to nije jedini način na koji se može shvatiti posjedovanje kontrole nad izborom. Prema alternativnom shvaćanju, kako bi se moglo kazati da imam kon- 
trolu nad izborom hoću li učiniti A ili B, ja ne moram vjerovati da su A i B stvarno, fizički, otvorene opcije. Dovoljno je da vjerujem da su, koliko je meni poznato, A i B otvorene opcije, ili pak da ne vjerujem da su obje zatvorene. Drugim riječima, ne moram vjerovati $u$ istinitost indeterminizma. Čak i ako je istinit determinizam i zapravo je otvorena samo jedna opcija, kada izaberem tu opciju i djelujem u skladu s njom, ja manifestiram svoju kontrolu nad onim što činim jer sam izabrao u skladu s onim što mislim da znam, naime da mogu učiniti i A i B. Dakle, ako razmišljam o tom hoću li obući plavu ili bijelu košulju i izaberem bijelu, onda, čak i ako je determinizam istinit i ako je bilo neizbježno da izaberem bijelu košulju, ja sam, prema tom objašnjenju, birao, to jest postupao u skladu s onim za što sam mislio da znam, naime da mogu izabrati bijelu i da mogu izabrati plavu košulju. A ako poslije kažem "Mogao sam učiniti drukčije i izabrati plavu košulju", onda to ne znači da se obvezujem na zamisao da su mi u trenutku izabiranja stvarno, fizički, otvorene bile obje opcije i da sam u posve istim okolnostima mogao izabrati plavu košulju. To samo znači da sam imao neku vrstu opće sposobnosti da izaberem plavu košulju, ili da bih izabrao plavu košulju da su stvari bile drukčije — da sam, probudivši se toga jutra drukčije raspoložen, razmišljao i odlučio drukčije.

To su dva sasvim različita načina shvaćanja kontrole koja se manifestira kao sposobnost izabiranja. Ali ona se uopće ne mora shvaćati tako. Može se kazati da imati kontrolu nad svojim radnjama znači biti začetnik radnje, biti njezin kauzalni izvor. Prema takvu shvaćanju, moje oblačenje bijele košulje slobodno je ne zato što sam mogao izabrati plavu te sam tako manifestirao svoju kontrolu nad onim što činim, nego zato što sam ja (a ne netko drugi) taj koji je izvor procesa koji je doveo do mojega oblačenja bijele košulje. No što znači da sam ja izvor? Niz uzroka koji dovodi do radnje koju sam učinio ne završava u meni, nego se proteže dalje. Ja sigurno nisam početak toga niza pa stoga nisam ni krajnji izvor radnje. Stoga je moja kontrola nad onim što činim ipak samo djelomična. No kolika je točno kontrola potrebna? Ili je možda ipak potrebno da budem krajnji izvor kako bi se moglo kazati da imam kontrolu i da je moja radnja izraz moje slobodne volje?

\subsection{Problem slobode volje nije verbalan problem}

Ta dobro poznata razmatranja pokazuju da se za navedenu definiciju ipak ne može kazati da je usuglašena, to jest da nam nudi usuglašeni pojam slobode, jer samo malo razmišljanja o njoj može nas odvesti u sasvim različitim smjerovima. Ta bi nas razmatranja mogla navesti na pomisao da je spor oko definicije slobode zapravo samo verbalan. Jedna skupina filozofa smatra da sloboda zahtijeva sposobnost izbora između realno, fizički, otvorenih opcija. To neka bude I-sloboda (I kao "inkompatibilistička"). Druga skupina smatra da sloboda ne zahtijeva realno, fizički, otvorene mogućnosti. To neka bude K-sloboda (K kao "kompatibilistička".) Potom bi se moglo tvrditi da pod riječju "sloboda" jedni razumiju I-slobodu a drugi K-slobodu i da kada se spore oko slobode, tada nije riječ o pravom sporu, jer riječ "sloboda" za sudionike u sporu ne znači isto.

Ipak, spor nije samo verbalan. Kao što sam kazao, izraz "slobodna volja" svoje je značenje dobio i ima ga samo unutar tradicionalnoga okvira unutar kojega 
se je javio: slobodna je volja ono što neki smatraju ugroženim ako se uzme u obzir način na koji funkcionira svijet. Stoga pojam slobodne volje ne može a da u sebi ne uključuje određene pretpostavke o tom kako funkcionira svijet. Ne postoji neki pojam slobode koji bi bio neovisan o tim pretpostavkama i za koji bismo onda mogli pitati je li, te, ako jest, kako je instanciran u svijetu. I-sloboda i K-sloboda nisu, starinski govoreći, nominalne definicije - nije tako da su određene skupine filozofa stipulirale da "sloboda" znači I-sloboda ili K-sloboda niti su te definicije nešto što njima bliske jezične zajednice razumiju pod slobodom. Naprotiv, te su definicije formirane na temelju razmišljanja o tradicionalnom problemu slobode volje, koje uključuje razmišljanje o tom kako svijet treba funkcionirati da bi u njemu postojala slobodna volja. One su ishod razmišljanja o konceptualnim vezama između slobode, determinizma i indeterminizma. Ono što preostaje kao empirijsko pitanje jest funkcionira li svijet na relevantan način, a odgovor na to pitanje trebao bi pokazati je li pojam slobode instanciran u svijetu i koje od razmatranih konceptualnih veza ostaju samo konceptualne.

Ispada, na neki način, da oni koji iznose definicije slobode i objašnjenja koja proizlaze iz tih definicija uzimaju kao dokazano ono što tek treba dokazati. To je točno: oni u svoje definicije i objašnjenja ugrađuju gledište da svijet funkcionira na određeni način, no kako svijet zapravo funkcionira, to znanost tek treba pokazati. Stvar je, međutim, u tom što se unutar tradicionalnoga okvira i ne može drukčije postupati. Ono čemu svjedočimo osobito posljednjih pola stoljeća demonstracija je da je problem puno složeniji nego što se nekoć mislilo i da su konceptualne veze između slobode, determinizma, indeterminizma, naturalizma i nenaturalizma puno suptilnije nego što se možda pretpostavljalo.

\section{Zaključak}

Pokazao sam zašto filozofija i znanost same za sebe ne mogu ponuditi konačan odgovor na tradicionalan problem slobode volje. Proizlazi da konačan odgovor može ponuditi samo njihov združeni rad. Koji bi bio rezultat toga združenoga rada? Na strani znanosti imali bismo, u idealnom slučaju, kako sam već naznačio, definitivan skup istinitih iskaza barem o relevantnim dijelovima svijeta, ako ne i o svijetu u cjelini. Na strani filozofije imali bismo pak skup konceptualnih mogućnosti. Taj se skup konceptualnih mogućnosti danas sastoji od niza kondicionalnih iskaza o slobodi i srodnim (ili ovisnim) pojmovima — kondicionalnih zato što ti iskazi kao prešutne ili izričite antecedente sadržavaju pretpostavke o tom kako funkcionira svijet. Napredak znanosti pokazat ce koji su od tih antecedenata neistiniti, a razvoj filozofije, možemo pretpostaviti, pokazat će koje od preostalih konceptualnih mogućnosti moramo staviti na stranu, bilo zato što su nekoherentne, bilo zato što, zbog ovih ili onih razloga, više ne uživaju potporu filozofske zajednice. ${ }^{5}$

5 Mark Balaguer (2010) tvrdi da je ključno konceptualno (ili metafizičko, kako ga on naziva) pitanje imamo li libertarijansku slobodu (dakle slobodu nespojivu s determinizmom), a ono se u osnovi svodi na empirijsko, i još uvijek otvoreno, pitanje o uzročnoj povijesti određenih neuralnih 
Skup konceptualnih mogućnosti koji će nam na koncu u tom idealnom slučaju preostati neće biti takav da ćemo iz njega jednostavno moći iščitati rješenje problema. Taj će skup i dalje biti preširok, kakav je i sada. Znači li to da će nam sloboda volje zauvijek ostati tajnovitom, i to zbog nesposobnosti filozofije da poluči onakvu vrstu rezultata kakvu navodno može polučiti znanost? To je pitanje jednostavno pogrešno postavljeno, i to zbog najmanje dva razloga.

Kao prvo, tvrditi da filozofija zbog svojih ograničenja ne može riješiti problem slobode volje (ili, točnije, učiniti ključan korak u njegovu rješavanju, naime ogoliti konceptualne mogućnosti do minimuma), u onom smislu izraza "riješiti problem" u kojem probleme rješavaju znanstvenici ili inženjeri, znači preuzeti filozofski problem i primijeniti na njega kriterije koji za njega ne vrijede. Problem slobode volje, kako sam naglašavao, filozofski je problem, a ono što filozofija radi raspravljajući o svojim problemima nije ništa drugo nego ispitivanje konceptualnih mogućnosti. Empirijski informirano ispitivanje konceptualnih mogućnosti, kakvo je karakteristično za suvremenu filozofiju, neke od tih mogućnosti eliminira a neke afirmira i dalje razrađuje, te pritom rasvjetljava druge pojmove, pokazujući pritom koliko je konceptualna mreža široka, koliko su odnosi među ključnim pojmovima složeni te, često, koliko je tradicionalan okvir preuzak i neprimjeren. To je ono što rade filozofi kada, u najširem smislu riječi, raspravljaju o slobodi volje. To se može, ako se tako hoće, nazvati "rješavanje problema slobode volje", no od njega se ne može očekivati davanje jednoga, definitivnoga odgovora, jer problem nikad nije ni bio shvaćen kao nešto što zahtijeva takav odgovor. "Rješavanje problema" samo je rad na njegovu boljem razumijevanju, kao i na boljem razumijevanju srodnih pojmova - u ovom slučaju, pojmova pravne i moralne odgovornosti, odluke, namjere, radnje itd. Stoga slobodna volja nije ništa tajnovito. Danas bolje nego ikada razumijemo što je sve potrebno za njezino posjedovanje. No razumijemo, isto tako, koliko je tradicionalni okvir, koji u središte stavlja upravo pojam slobode volje, zapravo preuzak te bi nam možda bilo bolje bez njega. To pokazuje primjerice strawsonovska tradicija, koja u potpunosti napušta tradicionalni okvir.

Kao drugo, u gornjem je pitanju prešutno sadržana pretpostavka da moramo imati nekakvo definitivno rješenje problema slobode volje, da je riječ o problemu za koji je iznimno važno da ga riješimo. Ta je pretpostavka razumljiva: čini se da moramo imati takvo rješenje, jer ako se pokaže da nemamo slobodnu volju, onda, kako barem na prvi pogled izgleda, ne možemo biti ni pravno ni moralno odgovorni za ono što činimo, iz čega pak proizlaze daljnje krupne posljedice za društvo i svakoga od nas. No ta je pretpostavka ishitrena. Postoje snažni argumenti, koje su iznijeli primjerice David Hume u 18. i Roderick Chisholm u 20. stoljeću, prema kojima predmeti u strogom smislu riječi nisu numerički identični kroz vrijeme. No mi sigurno ne smatramo da moramo imati rješenje problema identiteta predmetâ i osoba kroz vrijeme kako bismo osobama mogli pripisivati primjerice pravnu od-

događaja. Stoga je slobodna volja "otvoreno znanstveno pitanje" (kako glasi dio naslova njegove knjige). To je primjer u kojem se konceptualno rješenje nudi puno prije empirijskoga. 
govornost. Sigurno ne smatramo da, ako se pokaže da ne postoji identitet predmetâ i osoba kroz vrijeme, onda se okrivljenik na sudu može braniti tvrdeći da on nije, strogo govoreći, ista osoba kao ona koja je nekoliko mjeseci ranije navodno počinila neki zločin. Razlog zbog kojega to ne smatramo također je konceptualan i tiče se razlike između konteksta u kojima vrijede različiti kriteriji pripisivanja identiteta. Isto vrijedi za slobodu volje. Sloboda volje filozofski je konstrukt kao i numerički identitet kroz vrijeme. Stoga tvrdnja da sloboda volje ne postoji ne povlači automatski, sama od sebe, tvrdnju da se okrivljenik pred sudom može braniti tako da kaže da nije kriv jer je istinit determinizam. Za takav je zaključak, kao i u slučaju identiteta, potreban dodatan konceptualni napor. ${ }^{6}$ Stoga je moguće da definitivan odgovor na pitanje o tom postoji li slobodna volja za naše živote ne bi značio baš ništa. Ako je slobodna volja tajnovita, ona je tajnovita baš kao i svaki drugi filozofski problem — ništa više i ništa manje. ${ }^{7}$

\section{Literatura:}

Aristotel (1894). Ethica Nicomachea. Ed. I. Bywater. Oxford: Oxford University Press.

Austin, John L. (1956-1957). A plea for excuses. Proceedings of the Aristotelian Society, New Series, 57, 1-30.

Balaguer, Mark (2010). Free Will as an Open Scientific Problem. Cambridge, Mass.: MIT.

Bargh, John A. (2008). Free Will is Un-natural. U: John Baer, James C. Kaufman i Roy F. Baumeister (ur.), Are We Free? Psychology and Free Will (str. 128-154). Oxford: Oxford University Press.

Bloom, Paul (2012). Free Will Does Not Exist: So What? The Chronicle of Higher Education, March 18, 2012. URL: https://www.chronicle.com/article/paul-bloom-free-willdoes-not/131170 (01.12.2018.)

Bourget, David; Chalmers, David J. (2013). What Do Philosophers Believe? Philosophical Studies, 170, 465-500.

Cashmore, Anthony R. (2010). The Lucretian Swerve: The Biological Basis of Human Behavior and the Criminal Justice System. Proceedings of the National Academy of Sciences of the United States of America, 107, 4499-4504.

Chivers, Tom (2010). Neuroscience, Free Will and Determinism: "I'm Just a Machine". The Telegraph, 12 October 2010. URL: https://www.telegraph.co.uk/news/science/8058541/Neuroscience-free-will-and-determinism-Im-just-a-machine.html (01.12.2018.)

Coyne, Jerry A. (2012a). Why You Don't Really Have Free Will. USA Today, January 1, 2012.

Coyne, Jerry A. (2012b). You Don't Have Free Will. The Chronicle of Higher Education, March 18, 2012. URL: https://www.chronicle.com/article/Jerry-A-Coyne-YouDont-Have/131165 (01.12.2018.)

6 Onakav napor kakav je vidljiv, primjerice, kod onih koji iz filozofskih razloga poriču moralnu odgovornost, kao što su Smilansky (2002) ili Pereboom (2014). Waller također poriče moralnu odgovornost, ali zadržava slobodnu volju: »Moralna odgovornost atavistički je ostatak sustava vjerovanja što smo ga mi (kao naturalisti) odbacili, i to s dobrim razlogom. Sloboda - i njezino poboljšanje - dobro se uklapa u naš prirodni svijet i naše znanstveno razumijevanje svijeta; moralna odgovornost ne (Waller, 2011, 40). Konceptualne su mogućnosti, dakle, puno šire nego što bi se na prvi pogled moglo činiti.

7 Ovaj je rad sufinancirala Hrvatska zaklada za znanost projektom 5343. 
Crick, Francis (1994). The Astonishing Hypothesis: The Scientific Search for the Soul. New York: Simon \& Schuster.

Fischer, John Martin; Ravizza, Mark (1998). Responsibility and Control: A Theory of Moral Responsibility. Cambridge: Cambridge University Press.

Fried, Itzhak; Mukamel, Roy; Kreiman, Gabriel (2011). Internally Generated Preactivation of Single Neurons in Human Medial Frontal Cortex Predicts Volition. Neuron, $69,548-562$.

Garvey, Brian (2018). The Situationist Challenge to Free Will. U: Filip Grgić i Davor Pećnjak (ur.), Free Will \& Action: Historical and Contemporary Perspectives (str. 71-87). Springer.

Gazzaniga, Michael S. (2011). Who's in Charge? Free Will and the Science of the Brain. New York: HarperCollins.

Gazzaniga, Michael S. (2012). Free Will is an Illusion, but You're Still Responsible for Your Actions. The Chronicle of Higher Education, March 18, 2012. URL: https://www. chronicle.com/article/michael-s-gazzaniga-free/131167 (01.12.2018.)

Greene, Joshua; Cohen, Jonathan (2004). For the Law, Neuroscience Changes Nothing and Everything. Philosophical Transactions of the Royal Society B, 359, 1775-1785.

Haggard, Patrick; Libet, Benjamin W. (2001). Conscious Intention and Brain Activity. Journal of Consciousness Studies, 8, 47-63.

Harris, Sam (2012). Free Will. New York: Simon \& Schuster.

Hawking, Stephen; Mlodinow, Leonard (2010). The Grand Design. New York: Bantam Books.

Hobbes, Thomas (2004). Levijatan ili Građa, oblik i moć crkvene i građanske države. Zagreb: Jesenski i Turk.

Inwagen, Peter van (1983). An Essay on Free Will. Oxford: Clarendon.

Inwagen, Peter van (2017). Thinking About Free Will. Cambridge: Cambridge University Press.

Knobe, Joshua; Nichols, Shaun (2017). Experimental Philosophy. U: Edward N. Zalta (ur.), The Stanford Encyclopedia of Philosophy. URL: https://plato.stanford.edu/archives/win2017/entries/experimental-philosophy/ (01.12.2018.)

Kožnjak, Boris (2015). Who Let the Demon out? Laplace and Boscovich on Determinism. Studies in History and Philosophy of Science Part A, 51, 42-52.

Libet, Benjamin W. (1985). Unconscious Cerebral Initiative and the Role of Conscious Will in Voluntary Action. Behavioral and Brain Sciences, 8, 529-566.

Libet, Benjamin W. (1999). Do We Have Free Will? Journal of Consciousness Studies, 6, 47-57.

McKenna, Michael; Pereboom, Derk (2016). Free Will: A Contemporary Introduction. New York: Routledge.

Mele, Alfred R. (2014a). Free: Why Science Hasn't Disproved Free Will. Oxford: Oxford University Press.

Mele, Alfred R. (2014b). Free Will and Substance Dualism: The Real Scientific Threat to Free Will? U: Walter Sinnott-Armstrong (ur.), Moral Psychology: Volume 4: Free Will and Moral Responsibility (str. 195-208). Cambridge, Mass.: MIT.

Miller, Christian (2017). Situationism, Social Psychology, and Free Will. U: Kevin Timpe, Meghan Griffith i Neil Levy (ur.), The Routledge Companion to Free Will (str. 407-422). New York: Routledge. 
Monroe, Andrew E.; Malle, Bertram F. (2015). Free Will without Metaphysics. U: Alfred R. Mele (ur.), Surrounding Free Will: Philosophy, Psychology, Neuroscience (str. 2548). Oxford: Oxford University Press.

Montague, Read (2008). Free Will. Current Biology, 18, R584-R585.

Nahmias, Eddy (2014). Is Free Will an Illusion? Confronting Challenges from the Modern Mind Sciences. U: Walter Sinnott-Armstrong (ur.), Moral Psychology: Volume 4: Free Will and Moral Responsibility (str. 1-25). Cambridge, Mass.: MIT.

Nelkin, Dana K. (2015). Freedom, Responsibility, and the Challenge of Situationism. Midwest Studies in Philosophy, 29, 181-206.

Paglieri, Fabio (2013). There's Nothing like Being Free: Default Dispositions, Judgments of Freedom, and the Phenomenology of Coercion. U: Andy Clark, Julian Kiverstein i Tillmann Vierkant (ur.), Decomposing the Will (str. 136-159). Oxford: Oxford University Press.

Pereboom, Derk (2014). Free Will, Agency, and Meaning in Life. Oxford: Oxford University Press.

Smilansky, Saul (2002). Free Will and Illusion. Oxford: Clarendon.

Soon, Chun Siong; Brass, Marcel; Heinze, Hans-Jochen; Haynes, John-Dylan (2008). Unconscious Determinants of Free Decisions in the Human Brain. Nature Neuroscience, 11, 543-545.

Strawson, Peter F. (1962). Freedom and Resentment. Proceedings of the British Academy, $48,1-25$.

Vargas, Manuel (2013). Situationism and Moral Responsibility. U: Andy Clark, Julian Kiverstein i Tillmann Vierkant (ur.), Decomposing the Will (str. 325-349). Oxford: Oxford University Press.

Waller, Bruce N. (2011). Against Moral Responsibility. Cambridge, Mass.: MIT.

Wegner, Daniel (2002). The Illusion of Conscious Will. Cambridge, Mass.: MIT.

\section{Free Will Between Philosophy and Science}

\section{Filip Grgić*}

\section{Summary}

The paper discusses the status of scientific views on free will, especially the view that free will is an illusion. It argues, firstly, that the problem of free will is a conceptual problem, in a very strict sense; secondly, that that which is standardly called "the problem of free will" is inseparable from the context within which it emerged, i.e., the philosophical attempt to solve the alleged conflict between freedom and determinism, and that outside this framework it has no meaning, and thirdly, that the term "freedom" as it is used in philosophical and scientific claims also has no independent meaning outside this framework. It follows that, among other things, a definitive solution to the problem of free will is not possible, but that this need not be of particularly important for human life.

Key words: determinism, free will, indeterminism, philosophy, science

* Filip Grgić, Ph.D., Director of the Institute of Philosophy in Zagreb. Address: Ul. Grada Vukovara 54, 10000 Zagreb, Croatia. E-mail: filip@ifzg.hr 